\title{
Differential Distribution of Closely Related Potassium Channels in Rat Schwann Cells
}

\author{
Huaiyu Mi, ${ }^{1}$ Thomas J. Deerinck, ${ }^{2}$ Mark H. Ellisman, ${ }^{2}$ and Thomas L. Schwarz ${ }^{1}$ \\ 'Department of Molecular and Cellular Physiology, Beckman Center, Stanford University, Stanford, California 94305 \\ and 2 San Diego Microscopy and Imaging Resource, Department of Neuroscience, School of Medicine, UCSD, La \\ Jolla, California 92093
}

\begin{abstract}
Closely related $\mathrm{K}^{+}$channels can coassemble to form heteromultimers in expression systems, as well as in vivo. Whether in vivo this coassembly is random and inevitable or whether highly homologous channels can be segregated and targeted independently within a given cell has not been determined. In this study, we address these questions by characterizing and localizing voltage-dependent $\mathrm{K}^{+}$channels in Schwann cells. Transcripts for three closely related members of the Shaker-like family of $\mathbf{K}^{+}$channels are found in adult rat sciatic nerve: Kv1.1, Kv1.2, and Kv1.5. We have examined two of these and observed that both Kv1.1 and Kv1.5 proteins are expressed in Schwann cells but differ in their distributions. Kv1.5 is localized on the Schwann cell membrane at the nodes of Ranvier and in bands that run along the outer surface of the myelin. It is also seen intracellularly in the vicinity of the nucleus. Schwann cell staining for Kv1.1, on the other hand, was seen only in perinuclear, intracellular compartments. These results provide evidence that closely related channels from the same family need not coassemble and can be localized differentially in the same cell. In addition, Kv1.1 was highly concentrated in the axonal membrane at juxtaparanodal regions. The distributions of these $\mathrm{K}^{+}$channels in myelinated nerve highlight the elaborate molecular specializations of these membranes.
\end{abstract}

[Key words: potassium channel, Schwann cell, node of Ranvier, Kv.1, Kv1.5, protein targeting, assembly, localization, glia]

$\mathrm{K}^{+}$channels are one of the most diverse class of ion channel known, yet the purpose of this diversity is still largely obscure. Since the first $\mathrm{K}^{+}$channels were cloned from the Shaker locus of Drosophila (Tempel et al., 1987; Kamb et al., 1988; Pongs et al., 1988; Schwarz et al., 1988), more than two dozen related genes have been cloned from various species, and their physiological properties and structures have been studied extensively in heterologous expression systems (see reviews by Jan and Jan,

\footnotetext{
Received Sept. 12, 1994; revised Nov. 28, 1994; accepted Dec. 21, 1994.

We thank Drs. J. Trimmer, R. Swanson, and G. Chandy for kindly providing $\mathrm{K}^{+}$channel clones. We also thank Dr. G. Lemke for cDNA libraries and Drs. $M$. von Zastrow, D. Daunt, and B. Kobilka for assistance with COS cell transfections. We thank Ms. I. Inman for outstanding technical assistance and Drs. B. Barres and W. Gilly for comments on the manuscript. This work was supported by NIH Grants GM42376 to T.L.S. and RR04050, NS14718, and NS26739 to M.H.E.

Correspondence should be addressed to Dr. Thomas L. Schwarz at the above address.

Copyright (C) 1995 Society for Neuroscience $0270-6474 / 95 / 153761-14 \$ 05.00 / 0$
}

1992; Salkoff et al., 1992). The function of these molecularly defined channels within their normal environment is less well understood. It has been difficult to correlate cloned and expressed channels with currents that are observed in vivo. Moreover, it is not known how channels become distributed in appropriate domains within the cell or how the association of subunits is regulated. Finally, in many cell types, the function of the channel in the physiology of the cell is not understood. This is particularly true in the case of voltage-dependent $\mathrm{K}^{+}$channels in electrically inexcitable cells such as Schwann cells.

Four families of voltage-dependent $\mathrm{K}^{+}$channels have been studied most intensively: Shaker, Shab, Shaw, and Shal (Salkoff et al., 1992). In accordance with a standardized nomenclature, the channels within these classes have been named KvI.n, $\mathrm{Kv} 2 . n, \mathrm{Kv} 3 . \mathrm{n}$, and Kv4.n respectively, where $\mathrm{n}$ is a number that specifies the individual member of the family (Chandy, 1991). Channels within the same family share greater homology than those in different families. Functional $\mathrm{K}^{+}$channels are composed of four subunits whose assembly is dependent on an identified cytoplasmic domain ( $\mathrm{Li}$ et al., 1992; Liman et al., 1992; Shen et al., 1993; Hopkins et al., 1994). Identical subunits may form homomultimers, or different subunits may form heteromultimers. In the Xenopus oocyte expression system, members from the same family have been found to coassemble freely to form heteromultimers (Christie et al., 1990; Isacoff et al., 1990; Ruppersberg et al., 1990). In contrast, channels from different families do not coassemble (Covarrubias et al., 1991). In vivo studies have confirmed that coassembly of members of the same family can occur (Sheng et al., 1993; Wang et al., 1993). Whether this mixing occurs randomly and inevitably in vivo or whether closely related channels can be either segregated from one another or assembled with a regulated subunit stoichiometry has not previously been determined.

In addition to assembling correctly, ion channels must be concentrated at appropriate regions in order to function properly. This has becn documented extensively for other channel types, such as $\mathrm{Na}^{+}$channels at nodes of Ranvier (Ellisman and Levinson, 1982) and acetylcholine receptors at neuromuscular junctions (Fertuck and Salpeter, 1974), and cytoskeletal proteins appear to be important in bringing about the membrane localization (Srinivasan et al., 1988). More recently, molecularly identified $\mathrm{K}^{+}$channels have also been localized to specialized membrane regions. Immunocytochemistry has shown that particular $\mathrm{K}^{+}$ channels can concentrate at specific domains in neurons such as presynaptic membrane, ccll bodics, dendrites, and nodes of Ranvier (Trimmer, 1991; Sheng et al., 1992, 1993; Hwang et al., 
1993; Wang et al., 1993, 1994). These studies have also shown that the targeting of an individual channel type is not invariant from one class of neuron to another; the channel that resides in the soma of one neuron may be concentrated at the terminals of another. What has not previously been shown, however, is whether a single cell that makes two members of the same family can distribute them differently within its membrane. Such a segregation of channels, as is descrihed in the present study, implies that $\mathrm{K}^{+}$channel assembly is likely to be controlled in vivo.

Schwann cells, as well as other glial cells, are known to contain voltage-dependent ion channels (reviewed by Barres, 1990; Chiu, 1991; Ritchie, 1992). $\mathrm{K}^{\prime}$ and $\mathrm{Na}^{\prime}$ channels were first described in Schwann cells in 1984 (Chiu et al., 1984). Since then, delayed rectifiers, transient A-type channels, and inward rectifiers have all been reported in cultured and acutely dissociated Schwann cells (Chiu et al., 1984; Shrager et al., 1985; Howe and Ritchie, 1988; Konishi, 1989; Verkhratsky et al., 1991). The repertoire of $\mathrm{K}^{+}$channels changes during development (Wilson and Chiu, 1990a) as well as under different culture conditions, but the purpose of these channels remains to be determined. Electrophysiological studies of myelinated nerve found evidence for $\mathrm{K}^{+}$channel localization in Schwann cells, where paranodal membranes show a 40 -fold higher density of $\mathrm{K}^{+}$currents than cell bodies (Wilson and Chiu, 1990b). This indication of a regional specialization of $\mathrm{K}^{+}$channels in Schwann cells motivated us to examine the nature and distribution of channels in these cells by molecular and immunocytochemical approaches.

In this study, we have identified several $\mathrm{K}^{+}$channels in rat Schwann cells. Polyclonal antibodies raised against two of them, Kv1.1 and Kv1.5 (also known as RCK1 and Kv1, Stuhmer et al., 1989; Swanson et al., 1990) were used to establish their distribution by immunofluorescent confocal microscopy and immunoelectron microscopy. These two channels have different patte ns of distribution in mature Schwann cells, demonstrating that very closely related channels that coassemble in oocytes can, nonetheless, be segregated and independently distributed in cells that normally express them. Both the axonal and Schwann cell membranes contain specialized regions with high concentrations of particular channels in the vicinity of the node. Understanding the fine structure of the node, particularly with respect to the location of ion channels, will be an important step towards elucidating the functions of these cells.

\section{Materials and Methods}

cDNA cloning. A rat Schwann cell cDNA library was kindly provided by Dr. Greg Lemke (Monuki et al., 1989). The library DNA was extracted by standard procedures (Maniatis et al., 1989) and $10 \mu \mathrm{g}$ of DNA were subjected to polymerase chain reaction with degenerate primers in the H5 and S6 regions. To identify members of the Shaker family, the primers were as follows: $5^{\prime}$ primer GCITT(T/ C)TGGTGGGCIGTIGT, and $3^{\prime}$ primer A(A/G)IACICCIGCIATIGC(A G)CA; for Shab and Shaw-related channels, 5' primer ATICCHIIIII(T/ C)TITGGTGGGC, and $3^{\prime}$ primer ACIATIA(T/C)IGGIA(T/C)IGGIA(A/ G)IGC; for Shal family members, the same 3' primer was used as for Shab and Shaw with the $5^{\prime}$ primer GCIGCITT(T/C)TGGTA(T/ C)ACIAT. The reaction was carried out in $10 \mathrm{~mm}$ Tris pH $8.3,50 \mathrm{~mm}$ $\mathrm{KCl}, 1.5 \mathrm{mM} \mathrm{MgCl}_{2}, 0.001 \%$ gelatine, $1 \mu \mathrm{M}$ of each primer, $0.2 \mathrm{mM}$ dNTPs, and 2.5 units Taq polymerase, for 40 cycles, with each cycle of $1 \mathrm{~min}$ at $94^{\circ} \mathrm{C}, 1 \mathrm{~min}$ at $42^{\circ} \mathrm{C}$, and $30 \mathrm{sec}$ at $72^{\circ} \mathrm{C}$. The PCR products were then fractionated on $2.5 \%$ Nusieve agarose gel and probed with a ${ }^{32}$ P-labeled detection oligo (ATGACIACIGTIGGITAT/CGG for the Shaker family and A/GTIACIATGACIACIITIGG for the Shab, Shal, and Shaw families). The labeled band was purified and subcloned into the TA cloning vector (Invitrogene). Individual clones were sequenced, and partial clones of Kv1.1, Kv1.4, and Kvl.5 were identified. The Schwann cell library was then screened for full length clones of Kv1.1 and Kv1.4 with the PCR-derived clones. Probes were labeled with $\alpha{ }^{3}{ }^{32} \mathrm{P}-\mathrm{dCTP}$ (DuPont) by heterohexamer random priming, and hybridizations were in $6 \times$ SSC, $0.5 \%$ SDS, $5 \times$ Denhardt's solution, and 100 $\mu \mathrm{g} / \mathrm{ml}$ salmon sperm DNA at $55^{\circ} \mathrm{C}$.

Transcript analysis. Total RNA from rat sciatic nerves and adult rat brain was isolated as described (Chomczynski and Sacchi, 1987). PolyA $^{+}$mRNA was prepared with the FastTrack Kit (Invitrogene). mRNA $(5 \mu \mathrm{g})$ was run on $0.8 \%$ agarose-formaldehyde gels, transferred to Genescreen nylon membrane (Dupont), and immobilized by UV cross-linking. Prehybridization (6-8 hr) and hybridization (16-24 hr) were done at $50^{\circ} \mathrm{C}$ for randomly primed ${ }^{32} \mathrm{P}$-labeled DNA probes in $50 \%$ formamide, $5 \times$ SSPE, $5 \%$ SDS, $5 \times$ Denhardt's solution, $330 \mu \mathrm{g} /$ $\mathrm{ml}$ salmon sperm DNA. The membrane was then washed in $0.1 \times \mathrm{SSC}$, $0.1 \% \mathrm{SDS}$ at $65^{\circ} \mathrm{C}$ for at least $1 \mathrm{hr}$ and subsequently exposed at $-80^{\circ} \mathrm{C}$ on Kodak film for $1 \mathrm{~d}$ to 1 week with an intensifying screen.

Antibody production. Peptides were synthesized by facilities at the Beckman Center, Stanford University. They were coupled to porcine thyroglobulin with glutaraldehyde (Harlow and Lane, 1988). Immunization was performed by Josman Laboratory. In brief, rabbits received $500 \mu \mathrm{g}$ of the peptides in the first immunization, and were boosted with $250 \mu \mathrm{g}$ every 4 weeks. Antisera were collected 1 and 2 weeks after each boost.

For affinity purification of the antibodies, Affigel-10 and 15 (BioRad) were used. Free peptide $(20 \mathrm{mg})$ in $1 \times$ PBS were incubated with a mixture of $2 \mathrm{ml}$ of each gel at $4^{\circ} \mathrm{C}$ overnight. The gels were then blocked by $0.2 \mathrm{M}$ glycine in $1 \times$ PBS for $1 \mathrm{hr}$ at room temperature and washed extensively with $1 \times$ PBS. The gels were incubated with $5 \mathrm{ml}$ of immunized sera diluted 1:5 in TS buffer (10 mM Tris pH 7.5 and $150 \mathrm{~mm} \mathrm{NaCl}$ ) at room temperature for $2-4 \mathrm{hr}$ with rotation. The gels were loaded onto a column and washed again with $25 \mathrm{ml}$ TS buffer and eluted in $1 \mathrm{ml}$ aliquots with $0.1 \mathrm{M}$ glycine $\mathrm{pH} 2.8$. The aliquots were collected into $50 \mu \mathrm{l}$ of $1 \mathrm{M}$ Tris-base solution to neutralize the acidity. Each aliquot was medsured al OD280, and the peak aliquots were stored in $150 \mathrm{~mm} \mathrm{NaCl}, 5 \mathrm{mg} / \mathrm{ml} \mathrm{BSA}, 10 \mathrm{mM} \mathrm{NaN}_{3}$, and $25 \%$ glycerol at $-80^{\circ} \mathrm{C}$.

Western blot analyses. 'Twenty sciatic nerves (approximately $1 \mathrm{gm}$ ) were homogenized in $10 \mathrm{ml}$ of $0.32 \mathrm{M}$ sucrose, $10 \mathrm{~mm}$ HEPES $\mathrm{pH} 7.0$, $1 \mathrm{mM}$ EGTA, $0.1 \mathrm{mM}$ EDTA, and $0.5 \mathrm{mM}$ PMSF, and then centrifuged at $1000 \times g$ for $10 \mathrm{~min}$. The supernatant (which contained almost all the immunoreactivity) was mixed with an equal volume of sample buffer of $0.125 \mathrm{M}$ Tris $\mathrm{HCl} \mathrm{pH} 6.8,4 \%$ SDS, $20 \%$ glycerol, and $1 \mu \mathrm{g} / \mathrm{ml}$ bromophenol blue. The samples were sonicated, heated at $100^{\circ} \mathrm{C}$ for 2 min, fractionated on a $10 \%$ acrylamide-SDS gel, and transferred to a nitroccllulose filter that was then blocked overnight at $4^{\circ} \mathrm{C}$ with $15 \mathrm{~mm}$ Tris $\mathrm{HCl} \mathrm{pH} \mathrm{7.5,0.13} \mathrm{M} \mathrm{NaCl,} 10 \mathrm{~mm}$ EDTA pH 7.0, $1 \%$ Tween 20 , and $0.1 \%$ gelatin. The filter was then blocked at room temperature for $1 \mathrm{hr}$ with $5 \%$ normal goat serum, $1 \%$ BSA, 5\% nonfat milk in PBI $(0.1 \%$ Tween in PBS). Antisera diluted 1:2000 for Kv1.1 and 1:1000 for $\mathrm{Kv} 1.5$ in PBT were incubated with the filters at room temperature for $2 \mathrm{hr}$ followed by six washes with PBT for a total of 1.5 to $2 \mathrm{hr}$ at room temperature. The immunoreactivity was visualized by enhanced chemoluminescence with an ECL kit (Amersham Life Science) and the manufacturer's suggested protocol.

Tissue culture and transfection. $\mathrm{Kv} 1.1$ and $\mathrm{Kv} 1.5 \mathrm{cDNA}$ were subcloned into the pCMV expression vector (Andersson ct al., 1988). COS cells from a stock flask were trypsinized and transferred to a $75 \mathrm{~mm}$ flask containing DMEM supplemented with $10 \%$ fetal calf serum and $50 \mathrm{Ing} / \mathrm{ml}$ gentamicin, grown overnight, and rinsed once with PBS. All incubations were at $37^{\circ} \mathrm{C}$ with $5 \% \mathrm{CO}_{2}$. The transfection mixtures of 5 $\mathrm{ml}$ PBS with $25 \mu \mathrm{g}$ of plasmid DNA for Kv1.1 or Kv1.5 and $2.5 \mathrm{mg}$ of DEAE dextran were added to the cells for $45 \mathrm{~min}$. The mixtures were removed and the cells were incubated for $3 \mathrm{hr}$ with $5 \mathrm{ml}$ of 51.6 $\mu \mathrm{g} / \mathrm{ml}$ chloroquine in supplemented DMEM, for $2.5 \mathrm{~min}$ in $10 \%$ DMSO in supplemented DMEM, and overnight in supplemented DMEM. The cells were trypsinized and transferred to sterilized $22 \mathrm{~mm}$ square No.1 coverslips in Petri dishes and incubated again in supplemented DMEM overnight prior to use for immunocytochemistry.

Immunocytochemistry. Rat sciatic nerves from freshly decapitated $>4$-week-old rats (Sprague-Dawley) were dissected and fixed in $4 \%$ formaldehyde in PBS on ice for $1 \mathrm{hr}$. Alternatively, sciatic nerves were dissected after the rat was perfused with $4 \%$ formaldehyde. The nerve was then desheathed and teased in order to expose single fibers. After several washes in PBS, the teased nerve was permeabilized in $0.2 \%$ 


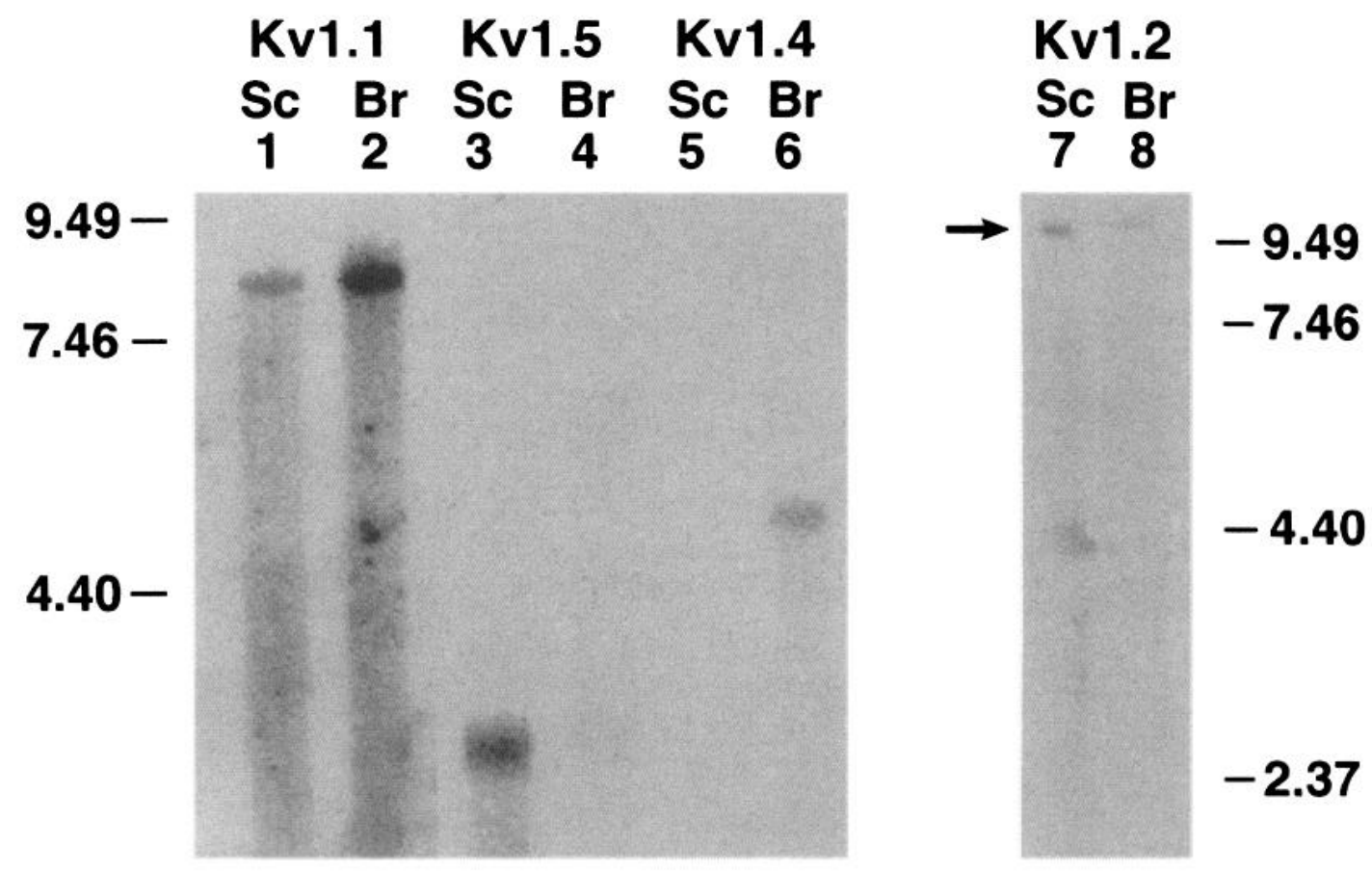

Figure 1. $\mathrm{K}^{+}$channel transcripts expressed in rat sciatic nerve and brain. RNA was extracted from adult rat sciatic nerve ( $\mathrm{Sc}$ ) or from whole adult brain $\left(\mathrm{Br}\right.$ ). Either $5 \mu \mathrm{g}$ of polyA ${ }^{+}$-selected mRNA (lanes $\mathrm{I-6}$ ) or $20 \mu \mathrm{g}$ of total RNA (lanes 7 and 8 ) were separated on $0.8 \%$ agarose gels and probed with portions of the open reading frames of channel clones Kv1.1 (lanes 1 and 2), Kv1.5 (lanes 3 and 4 ), Kv1.4 (lanes 5 and 6 ), and $\mathrm{Kv1} 2$ (lanes 7 and 8). Sciatic nerve contained detectable levels of Kv1.1, Kv1.5, and Kv1.2 transcripts and the sizes of the transcripts corresponded to those in brain: respectively, 8.5 kilobase $(\mathrm{kb}), 3.5 \mathrm{~kb}$, and $>10 \mathrm{~kb}$ (arrow). Kv1.4 transcripts could not be detected in adult sciatic nerve. Autoradiograms were exposed for $5 \mathrm{~d}$. Size standards, in $\mathrm{kb}$, are marked on either side.

Triton X-100 in PBS for 5 min. The nerve was preincubated in working buffer (5\% normal goat serum, $1 \%$ BSA, and $0.1 \%$ Triton $\mathrm{X}-100$ in PBS) for $1 \mathrm{hr}$ at room temperature, and was subsequently incubated with primary antibodies at $4^{\circ} \mathrm{C}$ overnight. Affinity purified anti-Kv1.1 and anti-Kv1.5 were diluted 1:10 to 1:40 in the working buffer. After several rinses with $0.1 \%$ Triton in PBS for $1.5-2 \mathrm{hr}$, a fluoresceinconjugated goat anti-rabbit IgG (1:200 in working buffer, Vector Lab) was applied for $1-2 \mathrm{hr}$ at room temperature followed by several rinses of PBT for a period of $30 \mathrm{~min}$. The samples were teased again, mounted on slides with Vectorshields (Vector Lab), and covered with No. 1 coverslips, and sealed with nail polish.

For cryostat sections of sciatic nerve, the nerve was dissected and fixed as above, and incubated in $10 \%, 20 \%$, and $30 \%$ sucrose in PBS for $30 \mathrm{~min}, 30 \mathrm{~min}$, and $2 \mathrm{hr}$, respectively. The nerve was either teased or directly embedded in OCT and quickly frozen in liquid nitrogen. Sections $(5 \mu \mathrm{m})$ were cut and collected on subbed slides. Sections were then permeabilized and stained as described above. In double labeling experiments, anti-Kv1.1 and monoclonal neurofilament antibody (SMI32, from Sternberger-Meyer Immunocytochemical) were mixed before application, as were the fluorescein-conjugated goat anti-rat and rhodamine conjugated goat anti-mouse secondary antibodies.

Coverslips with transfected COS cells were fixed by $4 \%$ formaldehyde in PBS for 5 min and stained as described above except that the incubation with primary antibody $(1: 100)$ was $1 \mathrm{hr}$ at room temperature.

Immunoelectron microscopy. Same-sized rats were anesthetized with Nembutal $(1 \mathrm{cc} / \mathrm{kg})$ and perfused transcardially with Ringer's solution followed by $4 \%$ formaldehyde (made fresh from paraformaldehyde) and $0.1 \%$ glutaraldehyde in $1 \times$ PBS for several minutes. The sciatic nerves were removed and fixed for an additional hour in the same fix on ice. Nerves were washed in PBS and incubated in $1 \mathrm{mg} / \mathrm{ml}$ collagenase (Sigma) in PBS for $10 \mathrm{~min}$ at room temperature. Following several washes in PBS, the nerves were embedded in $2 \%$ agarose and $80 \mu$ thick vibratome sections were cut. Sections were rinsed in PBS, blocked in working buffer (described above) for $1 \mathrm{hr}$ on ice, and incubated in primary antibodies with the same dilution as above at $4^{\circ} \mathrm{C}$ overnight. After washing with cold working buffer, the sections were incubated in biotinylated goat anti-rabbit secondary antibody for $1 \mathrm{hr}$. After further washing, the sections were incubated in avidin-biotin complex (Vector Labs) for $1 \mathrm{hr}$, washed again, and reacted in $0.5 \mathrm{mg} / \mathrm{ml}$ diaminobenzi- dine tetrahydrochloride with $0.02 \% \mathrm{H}_{2} \mathrm{O}_{2}$ for $6-8 \mathrm{~min}$. The sections were again washed in PBS, post fixed in $1 \%$ osmium tetroxide in PBS for $1 \mathrm{hr}$, and washed in distilled water. Following dehydration in acetone, sections were infiltrated in Durcopan ACM resin (Electron Microscopy Sciences) and polymerized at $60^{\circ} \mathrm{C}$ for $24 \mathrm{hr}$.

Three dimensional light microscopic images of peroxidase-labeled samples were obtained using the Edge Stereomicroscope (Edge Scientific). For conventional electron microscopy, $80 \mathrm{~nm}$ thick sections were cut on an Ultracut E (Leica) and viewed at $80 \mathrm{keV}$ with a JEOL $100 \mathrm{CX}$ electron microscope. Semithick sections $(0.25-1 \mu \mathrm{m})$ were examined at $400 \mathrm{keV}$ with a JEOL $4000 \mathrm{EX}$ electron microscope.

\section{Results}

Identification and expression of $K^{+}$channels in rat Schwann cells

For the initial cloning of $\mathrm{K}^{+}$channels, a cDNA library made from forskolin-treated cultured Schwann cells of newborn rat sciatic nerve (Monuki et al., 1989) was screened by polymerase chain reaction (PCR). Degenerate oligos were made according to the deduced amino acid sequence of the highly conserved $\mathrm{H} 5$ and S6 domains. We designed one pair of PCR primers and a detection oligo for each of the following families: Shaker, Shab, Shal, and Shaw (see Experimental Design). Three different partial sequences of $\mathrm{K}^{+}$channels in the Shaker family were found, but none were found for the other families. These sequences were identical to $\mathrm{Kv1} 1.1, \mathrm{Kv} 1.4$, and $\mathrm{Kv} 1.5$, respectively (Kv1.4 is also known as RCK4; Stuhmer et al., 1989). These PCR clones were later used to screen the cDNA library and the full length clones of Kv1.1 and Kv1.4 were isolated. The cDNA clone of Kv1.5 was kindly provided by Dr. R. Swanson.

Because the cDNA library was made from cultured cells, it may not accurately reflect the characteristics of Schwann cells in vivo. Each clone was used to probe a Northern blot with RNA from adult sciatic nerve and brain. Transcripts for both Kv1.1 
ANTI-KV1.5
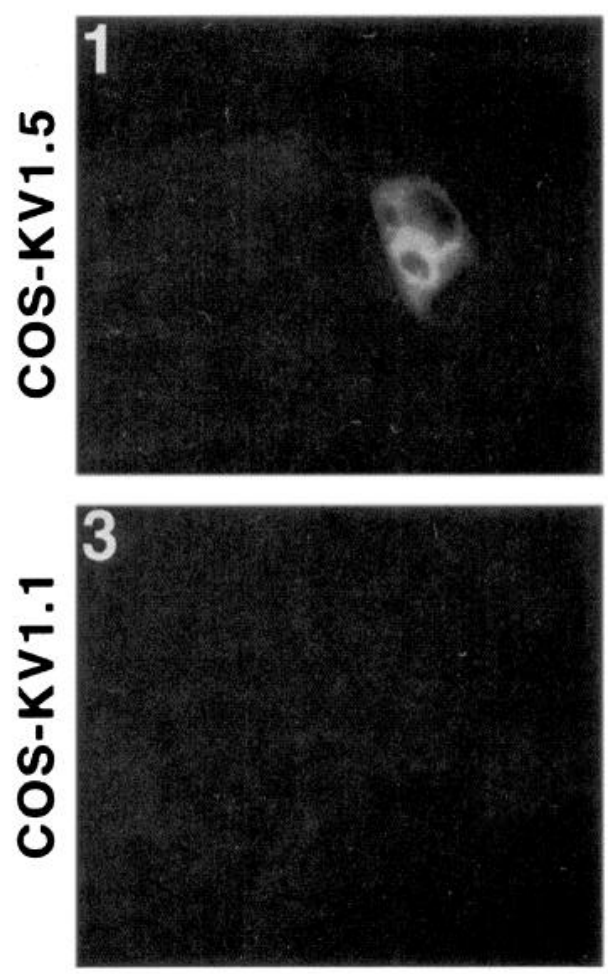

ANTI-KV1.1
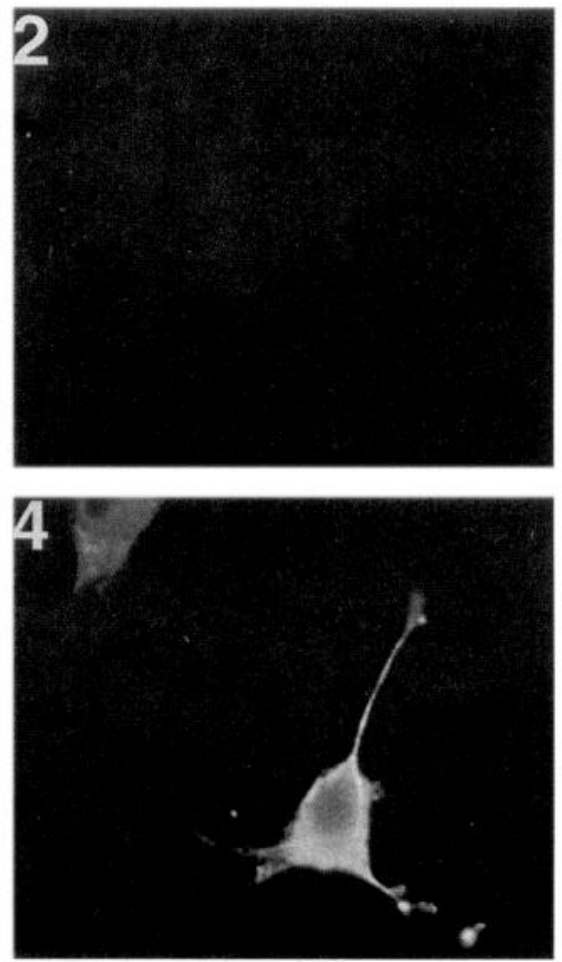
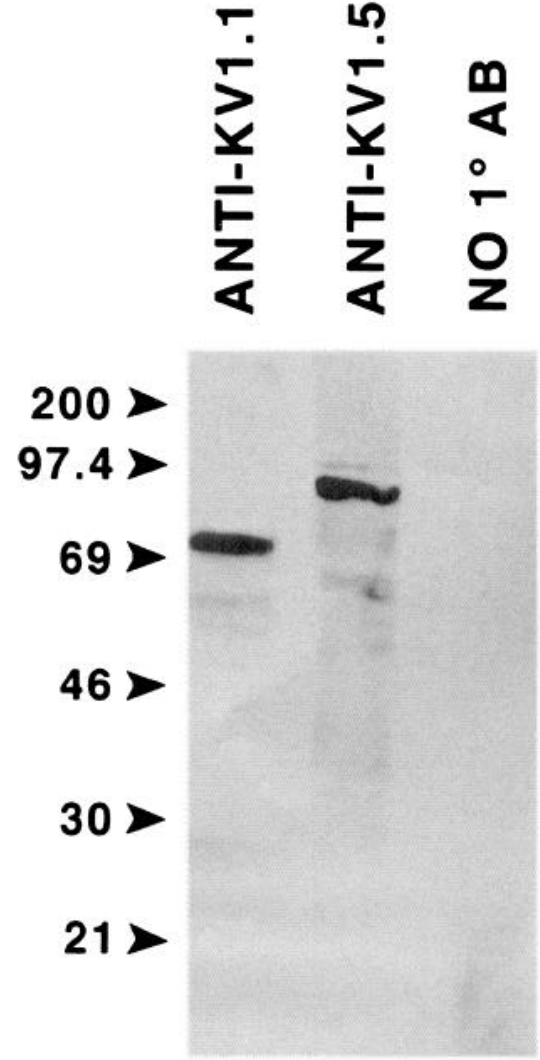

Figure 2. Specificity of antibodies against Kv1.1 and Kv1.5. A, COS cells were transfected with Kv1.5 (COS-Kv1.5; 1 and 2) and Kv1.1 (COS$K v 1.1 ; 3$ and 4$)$ in the pCMV expression vector. Cultures were stained with 1:100 dilutions of affinity purified antibodies against Kv1.5 (ANTI. $K v 1.5 ; I$ and 3 ) and Kvl.1 (ANTI-KvI.I; 2 and 4) and fluorescein-conjugated secondary antibody. Typically, 10-30\% of the cells in a culture were fluorescent when stained with the appropriate antibody, while no cross-reactive staining could be detected from the other antibody. $B$, The antisera recognize a single major band of the appropriate size in rat sciatic nerve. Equal amounts of protein were stained with antisera against Kvl.1 (diluted 1:2000) and Kv1.5 (diluted 1:1000), or without a primary antibody. The immunoreactivity was visualized by enhanced chemoluminescence (ECL). Size standards in kilodaltons are marked.

and Kv1.5 were detected in sciatic nerves (Fig. 1, lanes 1, 3), and their sizes corresponded to the previously described transcripts from brain ( 8.5 and $3.5 \mathrm{~kb}$; Fig. 1, lanes 2, 4). Kv1.4, on the other hand, was not detected in adult sciatic nerves (Fig. 1, lane 5). Kvl.4 transcripts were not observed in neonatal sciatic nerve either (data not shown). It is very likely that the transcript was induced by the culture conditions. Similarly, some genes expressed in vivo may not be well represented in the cultures. We therefore screened rat sciatic nerve RNA with a battery of $\mathrm{K}^{+}$channel clones. Besides the above two clones, Kv1.2 (also known as RCK5 or mk2) was present in sciatic nerves (Fig. 1, lane 7). No detectable expression for Kv1.3, Kv1.6, and Kv3.2 (also called Kv3, Kv2, and Kv4, respectively, Swanson et al., 1990) was found (data not shown). A very low level of Kv2.1 (also called DRK1, Frech et al., 1989) may be present in Schwann cells as well (data not shown). Our results are in agreement with an earlier report of Kv1.1 and Kv1.2 transcripts in mouse sciatic nerve (Chiu et al., 1994).

It is likely that the transcripts in sciatic nerve RNA derive from Schwann cells rather than axons since axons contain little or no mRNA. In addition, the presence of Kv1.1 and Kv1.5 in cDNA libraries from neuron-free cultured Schwann cells argues for a predominantly Schwann cell origin for the transcripts. Finally, though fibroblasts may have contributed some transcripts, the protein for both of these channels is present within the Schwann cell, as described below.
We have not examined in detail Schwann cells at other stages of development when their repertoire of $\mathrm{K}^{+}$channels may be altered. During Wallerian degeneration, for example, Schwann cell $\mathrm{K}^{+}$currents increase, and it has been proposed that $\mathrm{K}^{+}$channels are involved in Schwann cell proliferation (Chiu and Wilson, 1989). This is not likely to account for the channels described here because they are (1) present in mature, nondividing Schwann cells and (2) poorly expressed in cultures of proliferating Schwann cells (data not shown). In contrast, as described above, Kv1.4 was isolated from a library of cultured Schwann cells, but its expression in vivo in sciatic nerve could not be detected. Cultured Schwann cells may correspond to a prenatal proliferative state or Schwann cells of degenerating nerves, and may not be representative of mature Schwann cells of normal nerve. We have focused on Kv1.1 and Kv1.5.

\section{Antibody production}

Antibodies against Kv1.1 and Kv1.5 were raised to be used as tools for examining the channels' distribution in vivo. These channels share greater than $66 \%$ identity with each other and with other channels of the Shaker family, especially in the putative transmembrane domains and their flanking regions. To obtain isoform-specific sera, unique peptides were chosen from the more diverse carboxyl terminal of each clone: EDMNNSIAHYRQANIRTG (aa 458-475 of Kv1.1) and NQRRESGLDTGGQRKVSC (aa 529-546 of Kv1.5). When these sequences were 

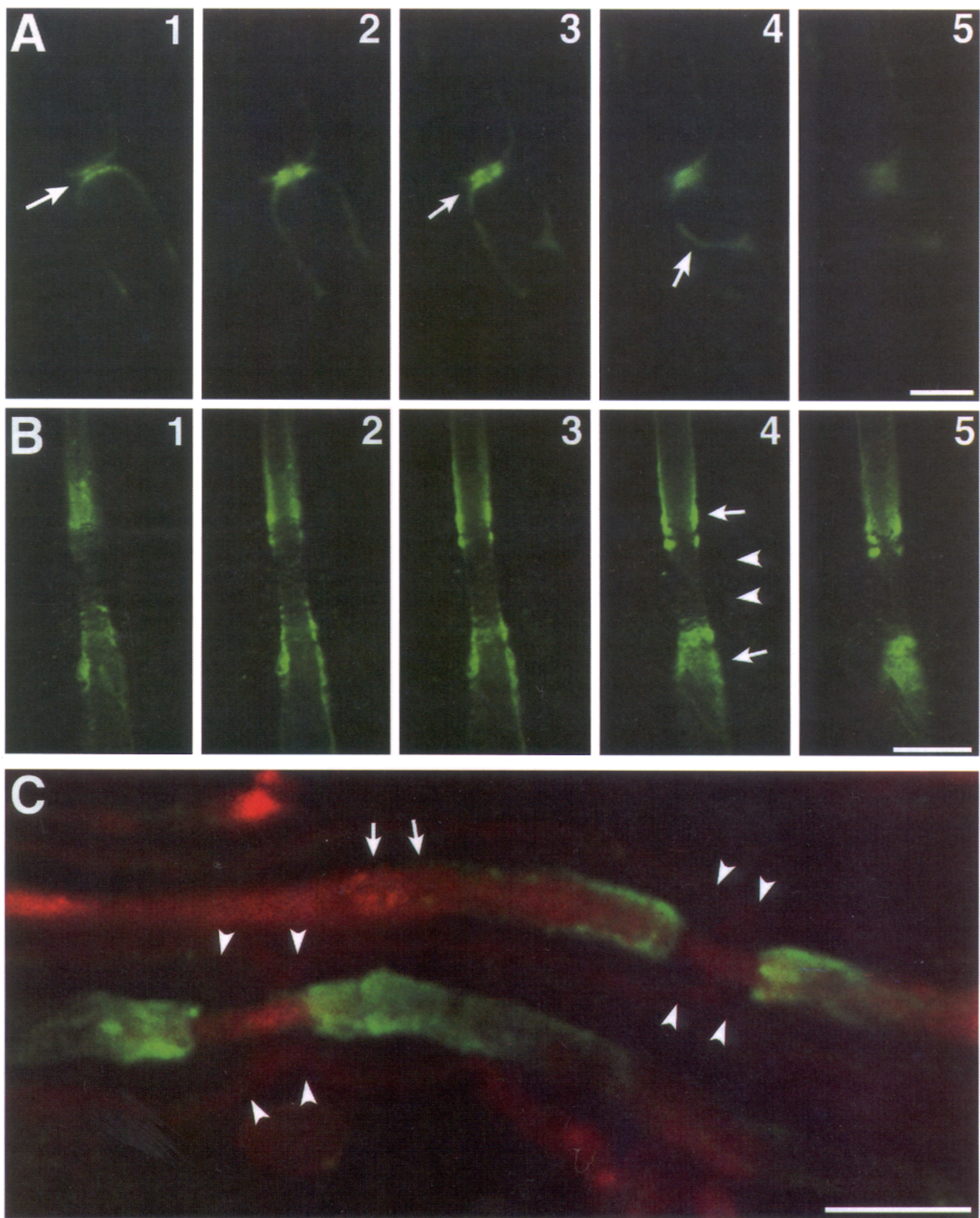

Figure 3. Immunofluorescent localization of Kv1.1 and $\mathrm{Kv} 1.5$ in teased adult rat sciatic nerve. Series of optical sections were taken at $1 \mu \mathrm{m}$ intervals using a laser-scanning confocal microscope. A, Kv1.5 was observed on the outer surface of the Schwann cells in the vicinity of the node. The stained membranes are slightly separated by the nodal gap (arrows Al,3). In other focal planes, bands of staining on the outer surface of the Schwann cell could also be seen (arrow, A4). B, Kvl.1 immunoreactivity was observed in the juxtaparanodal region to either side of the node at the interface of the axonal membrane and Schwann cell inner membrane (arrows B4). Little or no Kvl.1 staining was seen in the node or paranode (arrowheads B4) or on the outer surface of the Schwann cell. $C$. The localization of Kv1.1 to the juxtaparanode was apparent in $5 \mu \mathrm{m}$ cryostat sections of teased sciatic nerves that were double labeled with affinity purified antibody against Kvl.1 and a monoclonal antibody against neurofilaments. The signal of Kv1.1 was visualized by fluorescein fluorescence (green) and the signal of neurofilament was visualized by rhodamine fluorescence (red). Arrows show the internodal region, and arrowheads indicate the nodal and paranodal regions. Scale bars, $10 \mu \mathrm{m}$. 

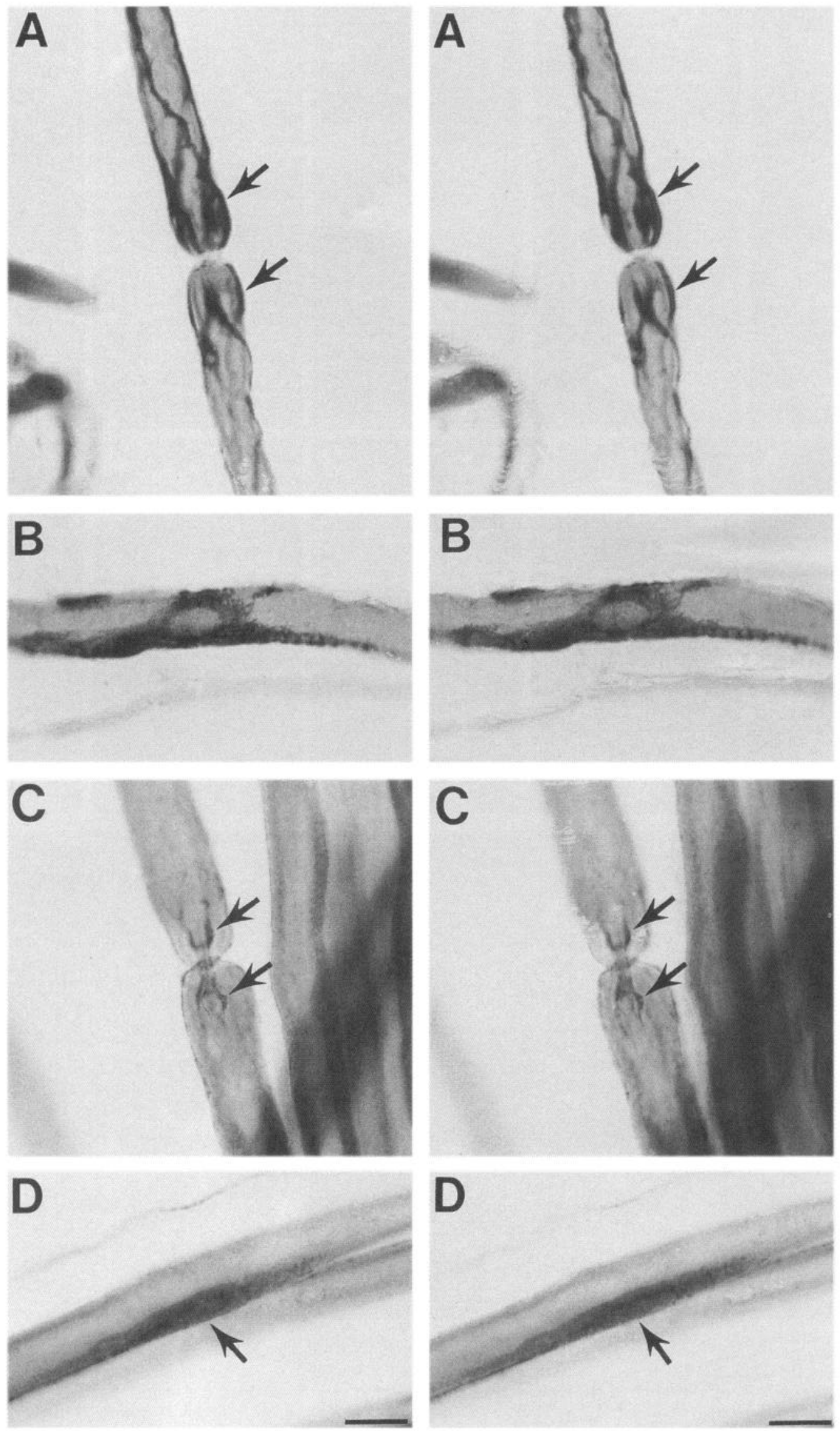

Figure 4. Stereo pair images of Kv1.5 and Kv1.1 immunoreactivity in adult rat sciatic nerves. Vibratome sections containing nodes of Ranvier $(A$ and $C)$ and perinuclear regions $(B$ and $D)$ were stained with affinity-purified antibodies against $\mathrm{Kv1.5}(A$ and $B)$ or Kv1.1 $(C$ and $D)$ and $\mathrm{HRP}$ - 
searched against the gene banks, no homology to any other $\mathrm{K}^{+}$ channels were observed.

The specificity of each antibody was tested by staining transfected $\mathrm{COS}$ cells (Fig. $2 A$ ). Anti-Kv1.5 strongly stained the COS cells transfected with Kv1.5 cDNA (Fig. $2 A I$ ), but failed to stain those transfected with Kv1.1 (Fig. 2A3). Anti-Kv1.1 antibody shows the same strong staining to COS cells transfected with Kv1.1 cDNA (Fig. 2A4), but not to those with Kv1.5 (Fig. 2A2). Much of the staining appeared to be intracellular, as if the channels were not efficiently transported to the plasma membrane. All the staining could be blocked by preincubating the antibodies with their respective peptide antigens (data not shown). For each peptide, two rabbits were immunized and gave consistent results in staining sciatic nerve that were not observed with preimmune sera. These reagents were therefore considered suitable for use in localizing the channel isoforms. The specificity of the antisera was checked by Western blotting of proteins extracted from sciatic nerves (Fig. 2B). The Kvl.1 antibody saw one major band at $75 \mathrm{kDa}$ that comigrated with an immunoreactive band from brain. This finding is in reasonable agreement with the size estimate of $72 \mathrm{kDa}$ reported by others (Wang et al., 1993). The $\mathrm{Kv} 1.5$ antibody saw a single major band at $87 \mathrm{kDa}$. The protein core of Kv1.5 is $66.6 \mathrm{kDa}$ (Swanson et al., 1990); the additional $20 \mathrm{kDa}$ that we observed is probably due to glycosylation and is comparable to the extent of glycosylation observed for other $\mathrm{K}^{+}$channels. It is somewhat larger, however, than was observed for Kv1.5 on immunoblot of GH3 cells (Takimoto et al., 1993); the channels in these pituitary-derived cells may be less heavily glycosylated. Both our antibodies also detected fainter, smaller bands that are likely to be degradation products, and perhaps some of the unglycosylated precursors.

\section{Determination of the distribution of Kvl.l and Kvl.5 proteins in adult rat sciatic nerve by light microscopy}

The localization of Kv1.1 and Kv1.5 protein in rat sciatic nerve was studied by using immunofluorescent staining and laser-scanning confocal microscopy. Rat sciatic nerves were dissected and teased until individual nerve fibers were sufficiently dissociated from one another to allow antibody penetration. The teased nerves were used for both Kv1.1 and Kv1.5 studies. Kv1.1 was also analyzed in cryostat sections.

The distribution of Kv1.5 is shown in a series of confocal optical sections in Figure $3 A$. The staining was most intense near the nodal region. The fluorescent labeling, as seen in Figure $3 A$, was mainly on the outer edge of the Schwann cell membrane as it curved towards the axon at the node of Ranvier and often appeared brightest close to the axon where the Schwann cell membranes faced into the nodal gap (Fig. 3A2,A3). A space could be seen between the stained membranes (Fig. 3A1,3A3, arrows). The outer surface of the myelin sheath at the internode was only faintly stained. Sometimes the staining on the outer surface of the myelin sheath showed thin lines of fluorescence running over the surface of the Schwann cells (Fig. 3A4, arrow). We ohserved this in more detail by staining the nerve with HRPconjugated secondary antibodies and examining thick specimens in bright field with the aid of a direct stereo-imaging light microscope (Fig. 4A). The staining appeared to be in tubular struc- tures within the outermost semicompact layer of the Schwann cells that forms the surface of the myelin sheath (Mugnaini et al., 1977). These structures, which we will hereafter refer to as canaliculi, appeared to represent regions of the Schwann cell surface where the outer two membranes are separated by thicker, organcllc-containing columns of cytoplasm (see below). These canaliculi emanate from the vicinity of the nucleus, wind over the surface of the Schwann cell, and extend out to the nodes (Fig. $4 A$ ). Staining could also be seen near the nucleus of the Schwann cell (Fig. 4B). No staining could be detected on any axonal membrane. The canalicular staining was more prominent when visualized with the HRP reaction than fluorescence but was observed with both methods (see above).

The staining for Kv1.1 was very different from that of Kv1.5 (Fig. $3 B, C$ ). The Kv1.1 protein appeared highly localized to the juxtaparanode (Fig. 3B4, arrows), a domain that lies to either side of the node just beyond the paranodal region (see below). In this region, the staining appeared at the contact surface between the myelin and the axonal membrane and, at the light microscope level, it was not possible to resolve whether the staining was of axonal or Schwann cell membranes. The nodal and paranodal regions of the axon (Fig. $3 B 4, C$, arrowheads) were very faintly stained. The relationship of the staining to the node could be seen most clearly when the position of the axon was visualized with rhodamine staining of neurofilaments (see Materials and Methods). The fluorescein-labeled Kv1.1 staining was diminished toward the internodal region even though the axon was still in the plane of focus (Fig. $3 C$, arrows). The observed signal in this juxtaparanodal region was not due to the trapping of antibodies in the space between these membranes hecause the staining pattern was the same in cryostat sectioned nerves (Fig. $3 C$ ) in which the thinness of the sections $(5 \mu \mathrm{m})$ assured that most axons $(5-8 \mu \mathrm{m}$ in diameter) would be cut open. Faint staining could also be seen around the nucleus of the Schwann cell (Fig. 4D, arrow). No signal was detected in regions where Kv1.5 was found to be concentrated: the outer surface of the Schwann cell membrane at the node and the canaliculi of the Schwann cells (Figs. $3 B, C ; 5 C$ ).

\section{Distinct distributions of Kv1.1 and Kv1.5 by electron microscopy}

The elaborate and specialized fine structure of the Schwann cell and node of Ranvier has been studied extensively by electron microscopy (Mugnaini et al., 1977; Wiley and Ellisman, 1980; Ellisman et al., 1984; Ichimura and Ellisman, 1991). The densely packed membranes of the myelin of the internode ensheathes the axon and includes little space for cytoplasm. At the paranode, where these wrappings terminate and attach to the axon, specialized cytoplasm-containing pockets are formed that appear in longitudinal section as finger-like lateral loops of membrane. At the nodal region, the narrow (1-2 $\mu \mathrm{m})$ gap between the two Schwann cells contains numerous microvilli that extend from the Schwann cells. The plasma membrane of the outer surface of the Schwann cell as it curves into the cleft frequently contains cytoplasm-filled grooves that separate the outermost membrane from the underlying myelin (Thomas et al., 1993). These cytoplasm-containing regions appear to be continuous with the can-

$\leftarrow$

conjugated secondary antibodies. Both channels appeared to be present in the vicinity of the Schwann cell nucleus $(B$ and arrows in $D)$, but only Kv1.5 antisera labeled the canalicular processes that extend along the outer surface of the myelin (A, arrows). In contrast, Kv1.1 staining appears within the fiber in the juxtaparanodal region $(C$, arrows). Scale bars, $10 \mu \mathrm{m}$. 

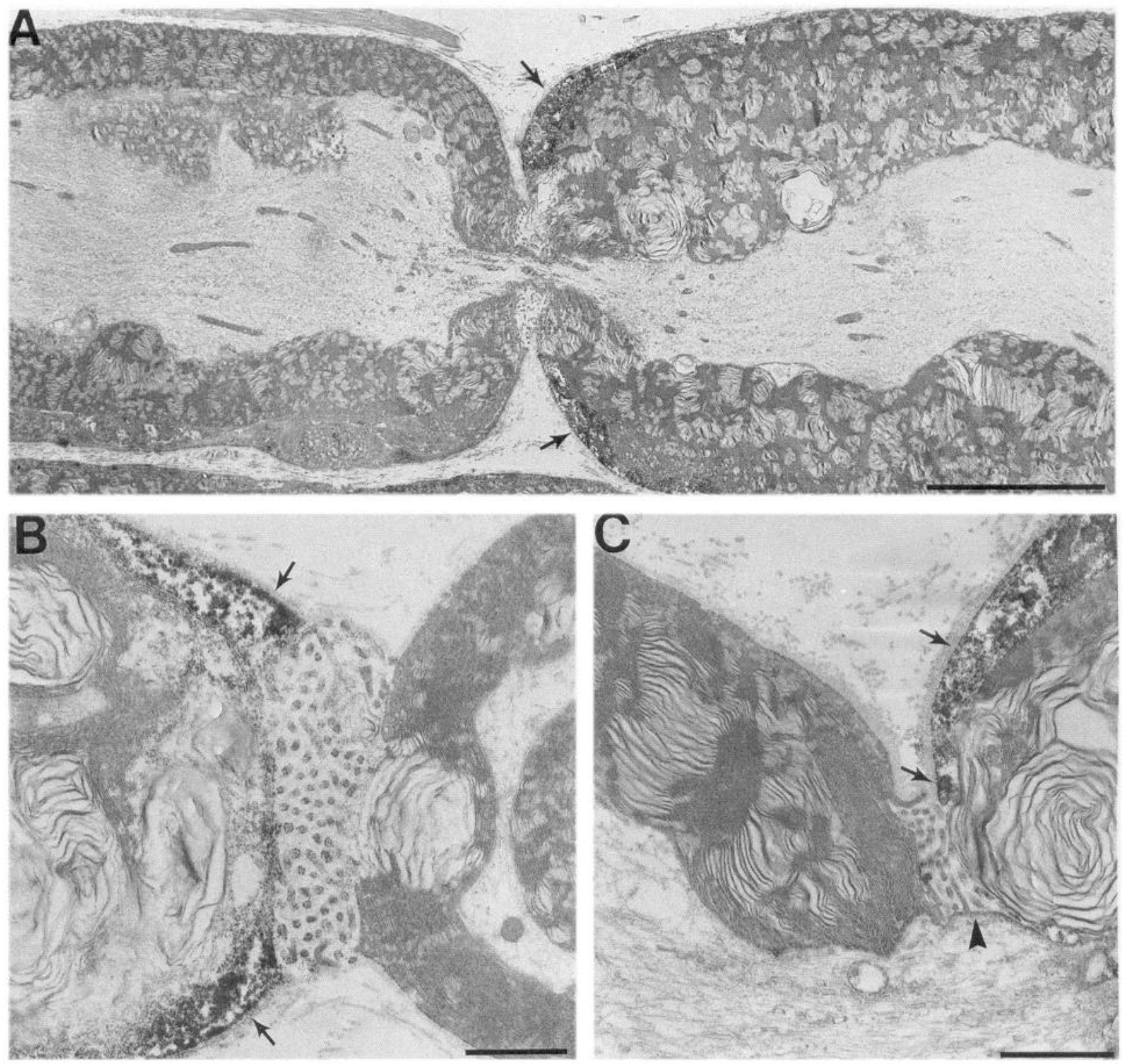

Figure 5. Immunoelectron microscopic localization of Kvl.5 at the nodes of Ranvier of adult rat sciatic nerve. A, Low magnification image of a section through a node of Ranvier. Arrows show the staining of Kv1.5 in the outer surface of a Schwann cell as it bends in towards the nodal gap. $B$, A higher magnification image of a section at a node, superficial to the position of the axon. Numerous microvilli can be seen in the nodal gap. Arrows indicate the staining by antibodies to Kv1.5 of regions of the Schwann cell that contain a thickened layer of cytoplasm. $C$, The nodal and paranodal specializations of the Schwann cell and axon are seen in section at a higher magnification. Staining of Kv1.5 can be observed in the outer membrane and underlying cytoplasmic compartment of the Schwann cell (arrows). Nodal (arrowhead) and paranodal regions are not stained. On a few occasions, it was observed that the membrane overlying a cytoplasm-containing compartment at a node was not stained. An example of this is seen in $A$, where the bottom portion of the left heminode appear to contain cytoplasm but is not stained. Scale bars: $5 \mu \mathrm{m}(A), 1 \mu \mathrm{m}(B$ and $C$ ).

aliculi described above (Fig. 4). The axon also undergoes specialization at the node; the axon is generally of a larger diameter at the internode, appears irregular in cross-section in the juxtaparanodal region, and narrows considerably in the paranodal region and, to a lesser extent, in the nodal region. Immunoelectron microscopy with an HRP-conjugated secondary antibody was performed to localize the two $\mathrm{K}^{+}$channels described above relative to these highly organized membrane specializations.

Kv1.5 staining was most consistently encountered in the outermost layer of the Schwann cells near the node of Ranvier (Fig. 5, arrows), in agreement with the fluorescent staining (Fig. 3A). In general, the axolemma was not stained. In the Schwann cell, there was no staining detected in the compact myelin nor was it apparent in the lateral loops that abut the axon at the paranode. The HRP reaction product did not uniformly label the outer surface of the Schwann cell: it was preferentially in regions where there was cytoplasm underlying the outermost membrane. Sometimes the stained region extended down very close to the axonal membrane (Fig. $5 C$ ). Because the peptides against which these antisera were made are predicted to reside on the intracellular side of the channel, the HRP-reaction product was expected to accumulate in the cytoplasmic rather than extracellular spaces. The observed signals were consistent with this prediction and the widespread staining of the cytoplasm in these regions was 

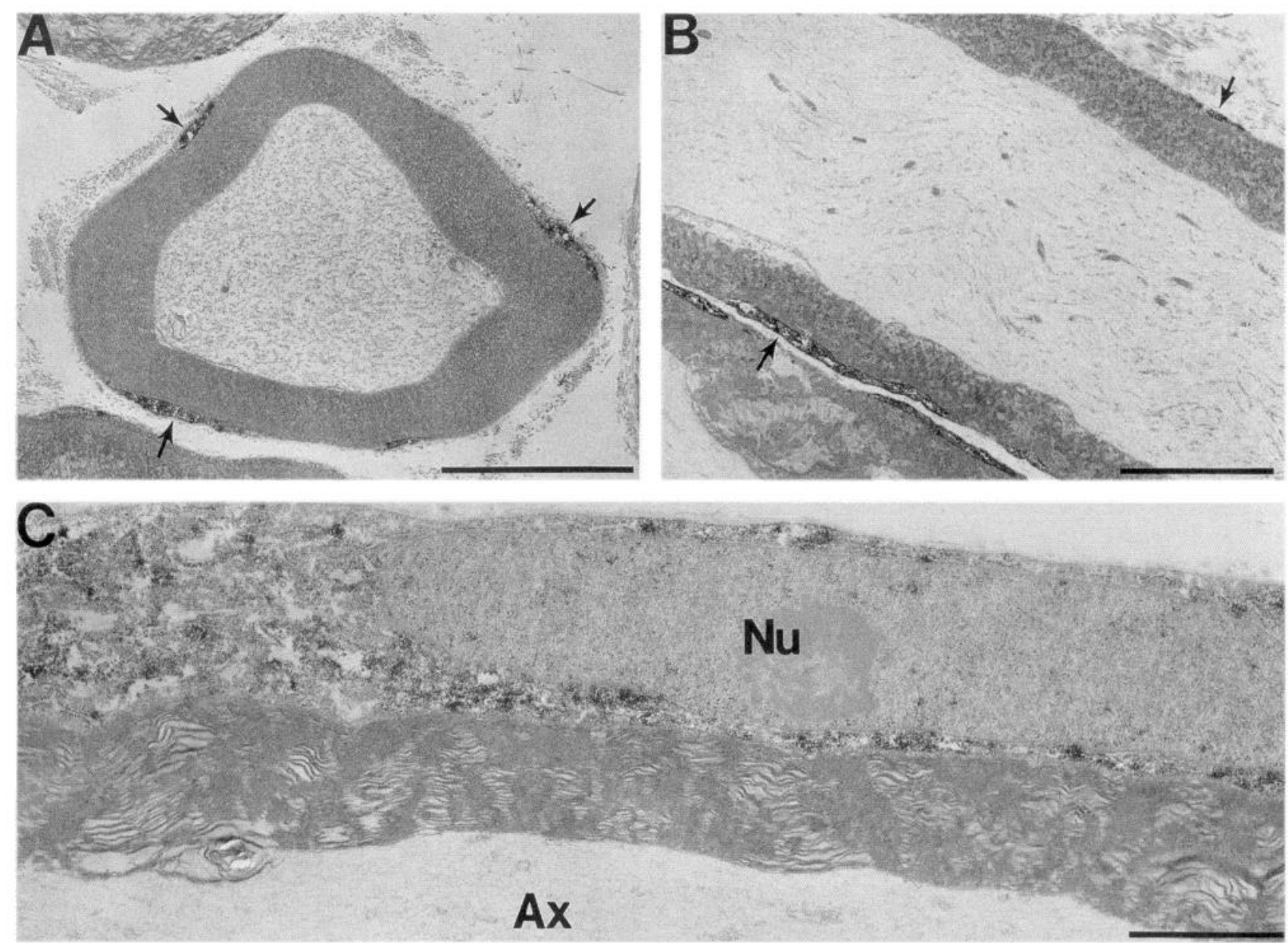

Figure 6. Immunoelectron microscopic localization of $\mathrm{Kv1.5}$ in the internode and perinuclear region of adult rat sciatic nerve. A cross-section $(A)$ and a longitudinal section $(B)$ of a nerve fiber in the internodal region show Kv1.5 staining in canaliculi of Schwann cells (arrows). In the Schwann cell perinuclear region $(C)$ the staining is mostly punctate in cytoplasmic compartments rather than on the plasma membrane. $A x$, axon; $N u$, Schwann cell nucleus. Scale bars: $5 \mu \mathrm{m}(A$ and $B), 1 \mu \mathrm{m}(C)$.

probably due to the diffusion of the HRP reaction product from membrane-associated channels.

Asymmetric staining was often observed, with one side of a node stained but not the other (Fig. 5). The staining pattern also varied; in a given section of a node, the stained compartment was sometimes not as close to the node or was represented by only a small patch of HRP-stained membrane. We had not anticipated this degree of variability from the fluorescent microscopy described above, and it may arise from a number of causes, including incomplete access of the HRP-conjugated antibodies to the Schwann cell cytoplasm. It seemed more likely that this discrepancy was due to the thickness of confocal optical sections $(1 \mu \mathrm{m})$, which would be much more likely to include cytoplasmassociated membrane compartments than the much thinner sections taken for EM. On a few occasions, it was observed that the membrane overlying a cytoplasm-containing compartment at a node was not stained (see Fig. 5A); the distribution of the channels may be patchy.

In the internode, Kv1.5 could also be detected on membranes of cytoplasmic compartments on the outer surface of the Schwann cell, presumably the canaliculi (Fig. $6 B$, arrows). The staining of the canaliculi could also be seen in cross-sections as small patches of cytoplasm containing the reaction product (Fig. $6 A$, arrows). This pattern was in agreement with the staining of canaliculi observed in the light microscope. Little or no staining for Kv1.5 was found along the portion of the plasma membrane overlying or near the Schwann cell nucleus (Fig. $6 C$ ). However, there was punctate staining in the cytoplasm (Fig. 6C), suggesting that the channel resides in an intracellular membrane compartment in the perinuclear region. This staining pattern is in agreement with the electrophysiology of Wilson and Chiu (1990b) who found $\mathrm{K}^{+}$current density to be very low in the cell body and much higher in the vicinity of the node.

Kv1.1 staining in the Schwann cell was most apparent as discrete intracellular puncta within the cytoplasm in the vicinity of the nucleus (Fig. 7C). Staining for this channel did not appear to be on the plasma membrane in this perinuclear region, along the canaliculi, or in the nodal regions where Kv1.5 was found (Fig. 7A) although occasional intracellular puncta were observed in these zones. Thus, the patterns of Kv1.1 and Kv1.5 expression within the Schwann cell were not the same.

As expected from light microscopy, Kv1.1 staining was most prominent at the juxtaparanodal region at the axon-Schwann cell interface (Fig. 7A, arrows). Because of the close association of the axonal and Schwann cell membranes, it was difficult even with electron microscopy to determine in which cell the channels resided. In general, the HRP reaction product was associated with the cytoplasmic surface of the axonal side, indicating an 

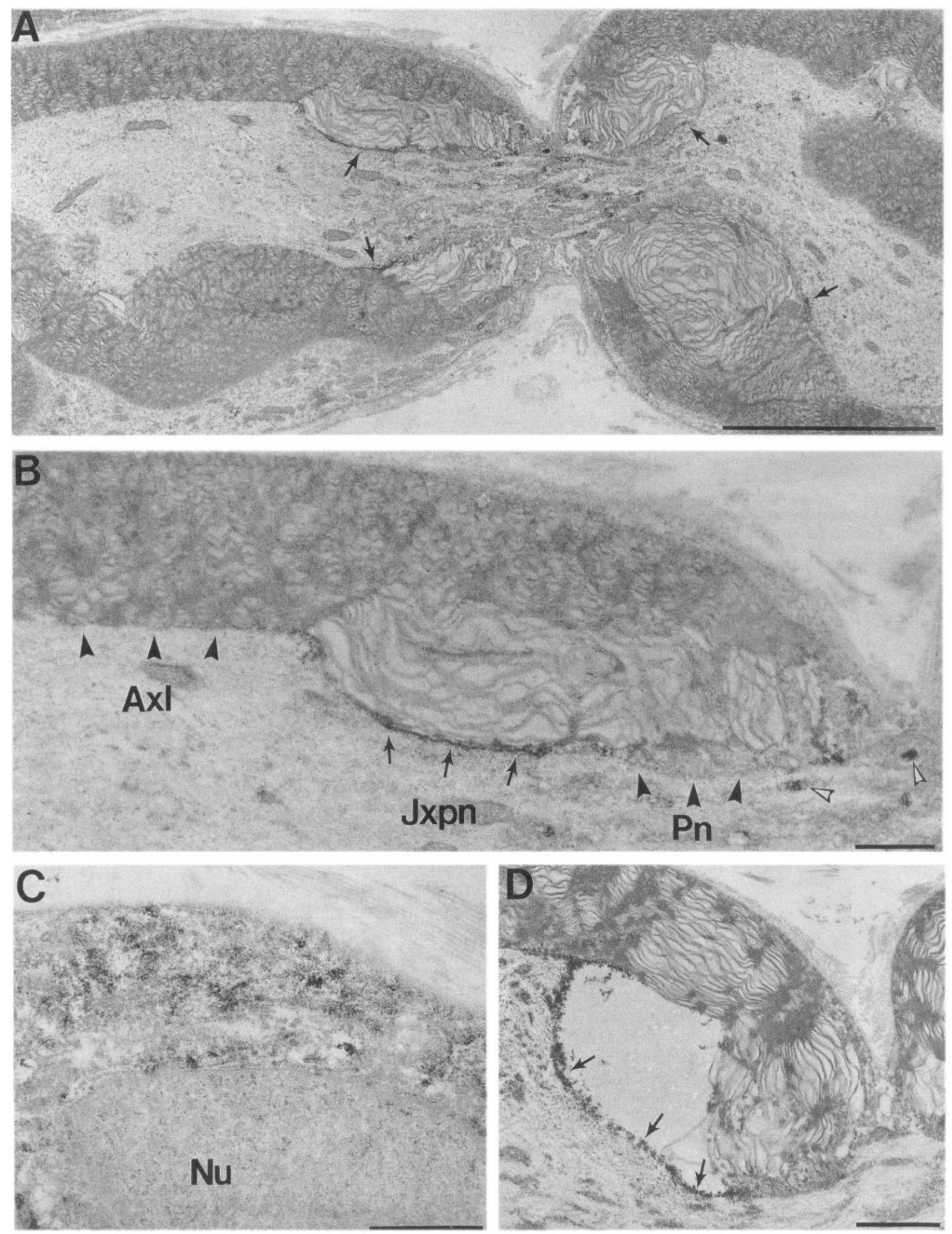

Figure 7. Immunoelectron microscopic localization of Kv1.1 in adult rat sciatic nerve. A, Low magnification image of a node of Ranvier. The staining is most prominent in the juxtaparanodes (arrows). Puncta of staining within the axon can be seen at and near the node. B, A portion of the same node at higher magnification. The staining in the juxtaparanodal region (Jxpn) is associated with the cytoplasmic surface of the axonal plasmalemma (arrows). Intracellular staining near the node can be seen in the axon (open arrowheads). No signal can be seen in the paranode (Pn) 
axonal localization (Fig. $7 B$, arrows). This was confirmed in regions in which the myelin had separated from the axon (Fig. $7 D$, arrows). This pattern is similar to what has been described for CNS nodes of Ranvier by Wang et al. (1993), extends these to the peripheral nervous system, and is in agreement with electrophysiological studies of peripheral nerve (reviewed by Black et al., 1990). Occasionally, some staining was associated with Schwann cell membranes in these regions (Fig. $7 D$ ); we have not been able to determine if this is due to diffusion of HRPproduct from the axonal side, an incomplete separation of the membranes, or a low density of Kv1.1 on the Schwann cell. As predicted from the light microscopy, the staining did not continue into the internode, and the axon at the node and paranode were generally unstained (Fig. $7 B, D$, arrowheads). Within the axon, staining could be observed in small intracellular puncta, especially near the nodal region, that were likely to represent membranous organelles (Fig. $7 A, B$ ).

Thus, the electron microscopy was consistent with the light microscopic localization of both channels and indicated a high degree of specialization of both axonal and Schwann cell membranes. Within the Schwann cell, Kv1.1 and Kv1.5 clearly had different fates.

\section{Discussion}

\section{Distinct patterns of Kv1.1 and Kvl.5 in Schwann cells}

In this study, the transcripts for three delayed rectifying $\mathrm{K}^{+}$ channels, Kv1.1, Kv1.2, and Kv1.5, were found to be expressed in adult rat Schwann cells in vivo. Schwann cells therefore afforded us the opportunity to ask whether two highly homologous $\mathrm{K}^{+}$channels expressed in the same cell would necessarily coassemble and colocalize. Kv1.1 and Kv1.5 belong to the Shaker family, and they share $66 \%$ identity at the amino acid level. Within the suggested assembly domain, which is located upstream of the first transmembrane domain (Li et al., 1992; Hopkins et al., 1994), they share $84 \%$ identity. Since all such closely related members of the Shaker family have been shown to coassemble to form heteromultimers in oocytes, these two channels might also be expected to coassemble. Indeed, when Kv1.1 and Kv1.5 were attached head to tail, they were readily expressed as a functional heteromultimeric channel (Liman et al., 1992).

If assembly in vivo happens randomly in an unregulated way, one would expect that closely related $\mathrm{K}^{+}$channels would coassemble most of the time to form heteromultimers (Fig. 8). Immunocytochemistry would be predicted to find these channels colocalized within any single cell that expressed them. On the other hand, if assembly in vivo is regulated, homomultimers might be the predominant form and a segregation of closely related $\mathrm{K}^{+}$channels could occur (Fig. 8).

Schwann cells must possess a mechanism that prevents the Kv1.1 and Kv1.5 subunits from coassembling indescriminantly; many of the channels were clearly segregated from each other. Almost all the detectable Kvl.l protein appeared to remain in an intracellular compartment near the Schwann cell nucleus, while most of the Kvl.5 channels moved into the membranes of the canaliculi and became particularly concentrated near the node. Some channel coassembly may occur in the perinuclear
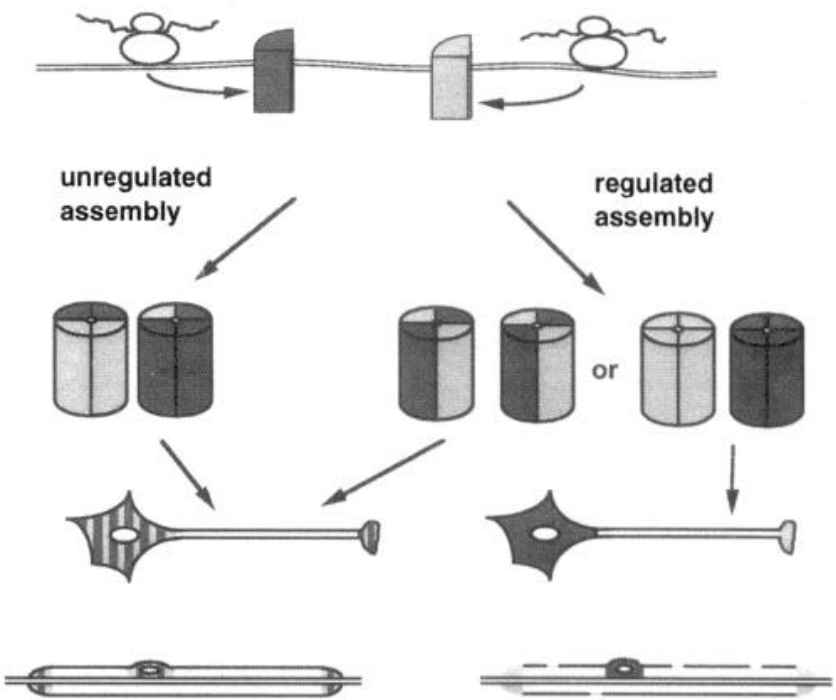

Figure 8. Assembly of $\mathrm{K}^{+}$channels and its implications for the regional specialization of cell membranes. This schematic diagram illustrates that unregulated mixing of different $\mathrm{K}^{+}$channels from the same family would result in a heterogeneous population of heteromultimers. Though a cell could restrict these heteromultimers to particular domains of the cell (e.g., neuronal cell bodies or terminals), coassembly would pose an obstacle to distinguishing those regions from one another. Regulated assembly could result in either heteromultimers or homomultimers. Segregation into dissimilar populations would permit the cell to target different family members to different regions of the cell. This is illustrated with a hypothetical neuron and, below, with a Schwann cell whose regulated segregation of channels summarizes the observed distribution of Kv1.1 (dark) and Kv1.5 (pale gray).

intracellular compartment. Because all our antisera were raised in rabbits, we did not directly contrast the two channels' distributions by double labeling a single cell. However, the high percentage of cells that were stained in a given region of welldissociated nerve $(>80 \%)$ excludes the possibility that these channels were expressed in separate, nonoverlapping subpopulations of Schwann cells.

Previous studies of $\mathrm{K}^{+}$channel distribution in the nervous system reported complex patterns of staining for $\mathrm{Kv} 2.1$ and Kv2.2 (DRK1 and CDRK; Hwang et al., 1993) and Kv1.1 and Kv1.4 (Sheng et al., 1993). These light microscopic studies generally could not always determine which cell's membranes contained the immunoreactive channels. Moreover, even in EM studies (Wang et al., 1993, 1994) the intricacies of the CNS did not permit the authors to know when they were looking at different regions of the same cell. Nevertheless, in light of our finding that cells can perform differential and independent localization of closely related channels, the complexity they observed in neurons of the CNS can most easily explained by invoking similar mechanisms.

The ability of closely related channels to be localized independently within a cell greatly increases the complexity of channel assembly and distribution. Were subunit mixing obligatory within a family, as was suggested by expression in heterologous systems, a cell would be severely limited in how closely it could

$\leftarrow$

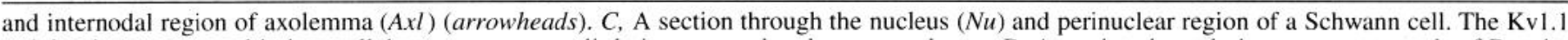

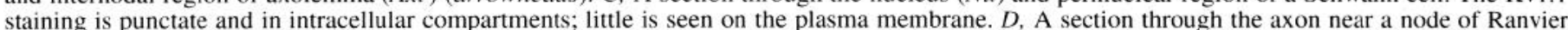

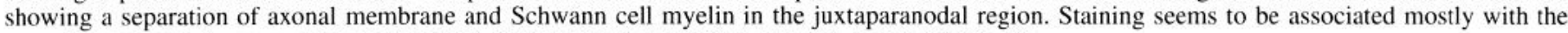
axonal membrane (arrows, also see Results). Scale bars: $5 \mu \mathrm{m}(A), 2 \mu \mathrm{m}(B), 1 \mu \mathrm{m}(C$ and $D)$. 
tailor the physiological properties of particular regions of the cell. To distinguish a dendrite from the soma, for example, a neuron would need to restrict to the dendrite the expression of one family (e.g., Kv1.n) and to the soma another (e.g., Kv2.n). The number of unique electrophysiological domains would be limited to the number of noncoassembling families. Thus, independently regulated targeting of $\mathrm{K}^{+}$channel isoforms may be important for achieving correct biophysical properties and susceptibilities to modulatory agents in nerve terminals, nodes of Ranvier, axon hillocks, the cell body, and regions within a dendritic tree.

How does the cell control subunit assembly and prevent undesired mixing? This control could be achicved at threc different levels. One possibility is that the information important for targeting is encoded in the mRNA (e.g., Macdonald and Struhl, 1988; Pollock et al., 1990). Both Kv1.1 and Kv1.5 transcripts have long untranslated regions ( $6 \mathrm{~Kb}$ and $2 \mathrm{~Kb}$, respectively). If transcripts for the two channels are targeted to different parts of the cytoplasm and translated in different ER compartments, coassembly may be preventable and the protein's destination may be determined by the ER compartment to which it was assigned. A second possibility is that sorting occurs at the protein level within the ER and Golgi apparatus before assembly into tetramers. In this case, the information directing assembly and targeting must reside in the unique amino acid sequences of each isoform of the channel and must be interpreted by proteins within the cell. Finally, heteromultimeric channels may form and subsequently undergo subunit exchange or rapid turnover.

\section{Correlation of cloned $K^{+}$channels and Schwann cell $K^{+}$ currents}

It is not presently known how accurately in vitro expression systems predict the physiological properties of a $\mathrm{K}^{+}$channel in vivo, and so it is difficult to correlate with confidence a molecular entity and a current. Wilson and Chiu (1990b) characterized the $\mathrm{K}^{+}$currents in the vicinity of the node in Schwann cells by enzymatical retracting the nodal myelin membrane. Because we have observed Kv1.5 channels in the vicinity of the node, Kv1.5 is a reasonable candidate for this current (Kvl.l appeared to remain within the Schwann cell body). For this correspondence to be correct, however, a comparison of the currents requires that the differences in the cellular milieu of Xenopus oocytes and Schwann cells bring about considerable differences in the properties of the channel. Wilson and Chiu described a delayed rectifying $\mathrm{K}^{+}$current that does not inactivate over at least 100 msec of depolarization, and in this regard, $\mathrm{Kvl} .5$ in oocytes is quite similar (Swanson et al., 1990) In $160 \mathrm{mM} \mathrm{K}^{+}$, the Schwann cell channel had a unit conductance of $13-14 \mathrm{pS}$; Kv1.5 has a unit conductance of $7.9 \mathrm{pS}$ in $120 \mathrm{mM} \mathrm{K}^{+}$(Matsubara et al., 1991). Much of the 0.6-fold difference in observed conductances can be accounted for by the 0.75 -fold difference in the concentrations of $\mathrm{K}^{+}$in these experiments. However there are substantial differences between the two currents. Schwann cell-delayed rectifiers were completely blocked by $70 \mathrm{mM}$ TEA. Kv1.5, however, is only partially blocked by $100 \mathrm{~mm}$ TEA (A. Villarroel, unpublished observation). The Schwann cell current has a half activation potential of about $-60 \mathrm{mV}$, while $\mathrm{Kv} 1.5$ in oocytes activates at a relatively more positive potential (half maximal at $-13 \mathrm{mV}$ ). These differences could be caused by several factors, such as the presence of a $\beta$ subunit in Schwann cells, a difference in posttranslational modification or some other conse- quence of differences in the cellular milieu. Alternatively, the currents observed by Wilson and Chiu may be generated by channels that have not yet been identified in this system. Though we have not yet localized Kv1.2 protein, the properties of Kv1.2 ( $K$ for TEA $=129 \mathrm{~mm}$, half-maximal activation $=-34 \mathrm{mV}$; Stuhmer et al., 1989) are very similar to those of Kv1.5 and so cannot easily account for the discrepancies in observed biophysical properties.

In other regards, our results are in agreement with the Schwann cell electrophysiology observed by other groups. Wilson and Chiu (1990a), in their recordings from cell bodies of acutely dissociated Schwann cells, detected very little $\mathrm{K}^{+}$current. Our immunohistochemistry shows little staining of either Kv1.1 or Kv1.5 on the plasma membrane of the cell body. Rapidly inactivating $\mathrm{K}^{+}$currents have only been found in cultured Schwann cells (Konishi, 1989; Verkhratsky, 1991), but not in paranodal Schwann cell membranes or mature Schwann cell bodies (Wilson and Chiu, 1990a,b). Appropriately, we found $\mathrm{K} v 1.4$, an inactivating $\mathrm{K}^{+}$channel, in a library from cultured Schwann cells, but did not observe any expression in adult Schwann cells in vivo.

\section{Functions of voltage-dependent $K^{+}$channels in nodes of Ranvier and Schwann cells}

From the distributions of Kv1.5 and Kv1.1 channels reported here, it is difficult to speculate on the functional significance of these channels in the Schwann cell. Several previous hypotheses have attempted to explain the presence of $\mathrm{K}^{+}$currents in terms of $\mathrm{K}^{+}$buffering at the node. During axon stimulation, a large efflux of $\mathrm{K}^{+}$occurs and contributes to the repolarization of the membrane. Elevation of the extracellular concentration of $\mathrm{K}^{+}$ can profoundly decrease the excitability of the axon, so prompt and efficient $\mathrm{K}^{+}$clearance may be crucial for nerve function. The Schwann cell was proposed to participate in this $\mathrm{K}^{+}$buffering process through a mechanism of either "spatial buffering" or "K+ accumulation" (for reviews, see Barres et al., 1990; Chiu, 1991). Both hypotheses require that some form of $\mathrm{K}^{+}$ channel permit $\mathrm{K}^{+}$entry into the Schwann cell and predict that a channel will be localized near the node where the $\mathrm{K}^{+}$is accumulating. The localization of Kv1.5, although near the node, is not ideal: the electron microscopy shows that it is localized at some distance from the axon. If the major accumulation of $\mathrm{K}^{\prime}$ is in the juxtaparanodal region, where $\mathrm{Kvl} .1$ resides in the axon, the $\mathrm{K}^{+}$will need to diffuse past the Schwann cell-axonal contacts in the paranode into the nodal cleft before it can reach the Kv1.5 channels. An inward rectifier that was localized closer to the axon would be more attractive as the influx pathway. Kv1.5 may, instead, serve as the channel for the subsequent efflux of $\mathrm{K}^{+}$from the Schwann cell. Extruded $\mathrm{K}^{+}$may travel a short distance in the extracellular space and then be recaptured by the axon via the $\mathrm{Na}^{+}-\mathrm{K}^{+}$ATPase pump, which has also been shown to localize at the nodal axonal membrane (Ariyasu et al., 1985). For Kv1.5 to function in the Schwann cell, whether to permit $\mathrm{K}^{+}$influx or its subsequent efflux, it seems necessary that its activation occur at potentials more negative than those required in Xenopus oocytes.

The ability of antibodies to Kv1.5 to mark the canaliculi of the Schwann cell demonstrates that these structures represent a previously unappreciated specialization of the outer surface of the myelin sheath and raises questions about the functional significance of these cytoplasm-filled compartments. It is likely that the canaliculi are necessary for the metabolic support of the 
nodal region and serve as a channel of communication between the cell body and outlying portions of the Schwann cell (see also Gasser in Frankenhaeuser, 1952). The presence of ion channels in the canaliculi, however, raises the possibilities of these structures' involvement in other processes (Funch and Faber, 1985).

The only place we could detect Kv1.1 protein in Schwann cells was intracellular puncta in the perinuclear region. What then is Kv1.1's function in the Schwann cell and is the channel ever present on the plasma membrane? There are several possibilities. (1) It may serve no purpose in the Schwann cell and may simply be turned over rapidly in the cell body. (2) In response to an unknown signal, this reserve pool of intracellular channels may be added to the membrane. (3) The protein could be present on the plasma membrane at a level below the reliability of our detection system; if the channel were distributed at a low level uniformly along the membrane, detection might be difficult. (4) The channel could be localized in the Schwann cell membrane just opposite the stained axonal juxtaparanodal region and the Schwann cell components overshadowed by the stronger axonal staining.

A fifth possibility is that the channels are transported from Schwann cells to the axonal membranes. Early findings showed that molecules such as amino acids, proteins, and lipids can be transferred from Schwann cells to axons in squid (Lasek et al., 1974; Lasek and Tytell, 1981; Kriegler et al., 1981). To explain $\mathrm{Na}^{+}$currents in vertebrate Schwann cells, it has been suggested that Schwann cells synthesize $\mathrm{Na}^{+}$channels that get transported to the axon (Gray and Ritchie, 1984; Ritchie et al., 1990). In the case of $\mathrm{K}^{+}$channels we are struck by the abundance of Kv1.1 channels in the axonal membrane immediately adjacent to the Schwann cell. Kv1.2 may also be at this location (Wang et al., 1993), and so it is of interest that transcripts for both these channels are in Schwann cells (see above and Chiu et al., 1992). Perhaps the Schwann cells transfer these channels to augment the supply of $\mathrm{K}^{+}$channels that is presumed to be transported down the axon to the node. However, the presence of considerable vesicle-associated Kv1.1 immunoreactivity within the axoplasm strongly suggests that axonal transport of this channel is occurring and therefore there is no necessity at this point to invoke an additional supply from Schwann cells.

In summary, we found Kv1.1, Kv1.2 and Kv1.5 expressed in adult rat Schwann cells and have examined the highly restricted distributions of Kv1.1 and Kv1.5 channels in myelinated nerve. Interestingly, although these channels are very similar and can coassemble with one another in a Xenopus oocyte, they show distinct localizations within the Schwann cell. Independent assortment of channels greatly enhances the potential ability of a cell to differentiate the electrical properties of particular membrane domains. These findings suggests that one reason for the enormous variety of $\mathrm{K}^{+}$channel genes may be the presence of unique targeting domains in their variable regions. The patterns of distribution also imply that cells have mechanisms, yet to be elucidated, that regulate subunit assembly and the subsequent localization of the different $\mathrm{K}^{+}$channel isoforms.

\section{References}

Andersson S, Davis DL, Dahlback H, Jornvall H, Russell DW (1988) Cloning, structure, and expression of the mitochondrial cytochrome P-450 sterol 26-hydroxylase, a bile acid biosynthetic enzyme. J Biol Chem 264:8222-8229.

Ariyasu RG, Nichol JA, Ellisman MH (1985) Localization of sudiun potassium adenosine triphosphatase in multiple cell types of the mu- rine nervous system with antibodies raised against the enzyme from kidney. J Neurosci 5:2581-2596.

Barres BA, Chun LY, Corey DP (1990) Ion channels in vertebrate glia Annu Rev Neurosci 13:441-474.

Black JA, Kocsis JD, Waxman SG (1990) Ion channel organization of the myelinated fiber. Trends Neurosci 13:48-54.

Chandy KG (1991) A simplified nomenclature for a family of vertebrate voltage-dependent $\mathrm{K}^{+}$channel genes. Nature 352:26.

Chiu SY (1991) Functions and distribution of voltage-gated sodium and potassium channels in mammalian Schwann cells. Glia 4:541558

Chiu SY, Wilson GF (1989) The role of potassium channels in Schwann cell proliferation in Wallerian degeneration of explant rabbit sciatic nerves. J Physiol (Lond) 408:199-222.

Chiu SY, Shrager P, Ritchie JM (1984) Neuronal-type $\mathrm{Na}^{+}$and $\mathrm{K}^{+}$ channels in rabbit cultured Schwann cells. Nature 311:156-157.

Chiu SY, et al. (1992) Soc Neurosci Abstr 18:185.6.

Chiu SY, Scherer SS, Blonski M, Kang SS, Messing A (1994) Axons regulate the expression of Shaker-like potassium channel genes in Schwann cells in peripheral nerve. Glia 12:1-11.

Chomczynski P, Sacchi N (1987) Single-step method of RNA isolation by acid guanidinium thiocyanate-phenol-chloroform extraction. Anal Biochem 162:156-159.

Christie MJ, North RA, Osburne PB, Douglass J, Adelman JP (1992) Heteropolymeric potassium channel expressed in Xenopus oocyte from cloned subunits. Neuron 2:405-411.

Covarrubias M, Wei AA, Salkoff L (1991) Shaker, Shal, Shab, and Shaw express independent $\mathrm{K}^{+}$current systems. Neuron 7:763-773.

Ellisman MH, Levinson SR (1982) Immunocytochemical localization of sodium channel distribution in the excitable membrane of Electrophorus electricus. Proc Natl Acad Sci USA 79:6701-6711.

Ellisman MH, Wiley CA, Lindsey JD, Wurtz CC (1984) Structure and function of the cytoskeleton and endomembrane systems at the node of Ranvier. In: Cellular neurobiology: a series, the node of Ranvier (Zagrocn J, Federoff S, eds), pp 153-181. New York: Academic.

Fertuck HC, Salpeter MM (1976) Quantitation of junctional and extrajunctional acetylcholine receptors by electron microscope autoradiography after ${ }^{125}$ I-alpha-bungarotoxin binding at mouse neuromuscular junction. J Cell Biol 69:144-158.

Frankenhaeuser B (1952) The hypothesis of saltatory conduction. Cold Spring Harbor Symp Quant Biol 17:27-36.

Frech GC, VanDongen AM, Schuster G, Brown AM, Joho RH (1989) A novel potassium channel with delayed rectifier properties isolated from rat brain by expression cloning. Nature 340:642-645.

Funch PG, Faber DS (1985) Measurement of myelin sheath resistances: implications for axonal conduction and pathophysiology. Science 225:538-540.

Gray PTA, Ritchie JM (1984) Ion channels in Schwann and glia cells. Trends Neurusci 8:411-415.

Harlow E, Lane D (1988) Antibodies: a laboratory manual. Cold Spring Harbor, NY: Cold Spring Harbor Laboratory.

Hopkins WF, Demas V, Tempel BL (1994) Both N- and C-terminal regions contribute to the assembly and functional expression of homo- and heteromultimeric voltage-gated $\mathrm{K}^{+}$channels. J Neurosci 14:385-93.

Howe JR, Ritchie JM (1988) Two types of potassium currents in rabbit cultured Schwann cells. Proc R Soc Lond (Biol) 235:19-27.

Hwang PM, Fotuhi M, Bredt DS, Cunningham AM, Snyder SH (1993) Contrasting immunohistochemical localizations in rat brain of two novel $\mathrm{K}^{+}$channels of the Shab subfamily. J Neurosci 13:1569-1576.

Ichimura T, Ellisman MH (1991) Three dimensional fine structure of cytoskeletal-membrane interactions at nodes of Ranvier. J Neurocytol 20:667-681.

Isacoff EY, Jan YN, Jan LY (1990) Evidence for the formation of heteromultimeric potassium channels in Xenopus oocytes. Nature 345:530-534.

Jan LY, Jan YN (1992) Structural elements involved in specific $\mathrm{K}^{+}$ channel functions. Annu Rev Physiol 54:537-555.

Kamb A, Tseng-Crank J, Tanouye MA (1988) Multiple products of the Drosophila shaker gene may contribute to potassium channel diversity. Neuron 1:421-430.

Konish $\mathrm{T}$ (1989) Voltage-dependent potassium channels in mouse Schwann cells. J Physiol (Lond) 411:115-130.

Kriegler JS, Krishnan N, Singer M (1981) Tropic interaction of neurons and glia. Adv Neurol 31:479-504. 
Lasek RJ, Tytell MA (1981) Macromolecular transfer from glia to the axon. J Exp Biol 95:153-165.

Lasek RJ, Garner H, Przybylski RJ (1974) Transfer of newly synthesized protein from Schwann cells to the squid giant axon. Proc Natl Acad Sci USA 71:1188-1192.

Li M, Jan YN, Jan LY (1992) Specification of subunit assembly by the hydrophilic amino-terminal domain of the Shaker potassium channel. Science 257:1225-1230.

Liman ER, Tytgat J, Hess P (1992) Subunit stoichiometry of a mammalian $\mathrm{K}^{+}$channel determined by construction of multimeric cDNAs. Neuron 9:861-871.

Macdonald PM, Struhl G (1988) Cis-Acting sequences responsible for anterior localization of bicoid mRNA in Drosophila embryos. Nature 336:595-598.

Maniatis T, Fritsch EF, Sambrook J (1989) Molecular cloning: a laboratory manual. Cold Spring Harbor, NY: Cold Spring Harbor Laboratory.

Matsuhara H, Liman ER, Hess P, Koren G (1991) Pretranslational mechanisms determine the type of potassium channels expressed in the rat skeletal and cardiac muscles. J Biol Chem 266:13324-13328.

Monuki ES, Weinmaster G, Kuhn R, Lemke G (1989) SCIP: a glial POU domain gene regulated by cyclic AMP. Neuron 3:783-793.

Mugnaini E, Osen KK, Schnapp B, Friedrich VL Jr (1977) Distribution of Schwann cell cytoplasm and plasmalemmal vesicles (caveolae) in peripheral myelin sheaths. An electron microscopic study with thin section and freeze-fracturing. J Neurocytol 6:647-668.

Pollock JA, Ellisman MH, Benzer S (1990) Subcellular localization of transcripts in Drosophila photoreceptor neurons: chaotic mutants have an aberrant distribution. Genes Dev 4:806-821.

Pongs O, Kecskemethy N, Muller R, Krah-Jentgens I, Baumann A, Kiltx HH, Canal I, Llamazares S, Ferrus A (1988) Shaker encodes a family of putative potassium channel proteins in the nervous system of Drosophila. EMBO J 7:1087-1096.

Ritchie JM (1992) Voltage-gated ion channels in Schwann cells and glia. Trends Neurosci 15:345-351.

Ritchie JM, Black JA, Waxman SG, Angelides KJ (1990) Sodium channels in the cytoplasm of Schwann cells. Proc Natl Acad Sci USA 87:9290-9294.

Ruppersberg JP, Schroter KH, Sakmann B, Stocker M, Sewing S, Pongs O (1990) Heteromultimeric channels formed by rat brain potassiumchannel proteins. Nature 345:535-537.

Salkoff L, Baker K, Butler A, Covarrubias M, Pak MD, Wei A (1992) An essential 'set' of $\mathrm{K}^{+}$channels conserved in flies, mice and humans. Trends Neurosci 15:161-166.

Schwarz TL, Tempel BL, Papazian DM, Jan YN, Jan LY (1988) Multiple potassium channcl components are produced by alternative splicing at the Shaker locus in Drosophila. Nature 331:137-142.

Shen NV, Chen X, Boyer MM, Pfaffinger PJ (1993) Deletion analysis of $\mathrm{K}^{+}$channel assembly. Neuron 11:67-76.

Sheng M, Tsaur ML, Jan YN, Jan LY (1992) Subcellular segregation of two A-type $\mathrm{K}^{+}$channel proteins in rat central neurons. Neuron 9:271-284.

Sheng M, Liao YJ, Jan YN, Jan LY (1993) Presynaptic A-current based on heteromultimeric $\mathrm{K}^{+}$channels detected in vivo. Nature 365:7275.

Shrager P, Chiu SY, Ritchie JM (1985) Voltage-dependent sodium and potassium channels in mammalian cultured Schwann cells. Proc Natl Acad Sci USA 82:948-952.

Srinivasan Y, Elmer L, Davis J, Bennett V, Angelides K (1988) Ankyrin and spectrin associate with voltage-dependent sodium channels in brain. Nature 333:177-180.

Stuhmer W, Ruppersberg JP, Schroter KH, Sakmann B, Stocke, M, Giese KP, Perschke A, Baumann A, Pongs O (1989) Molecular basis of functional diversity of voltage-gated potassium channels in mammalian brain. EMBO J 8:3235-3244.

Swanson R, Marshall J, Smith JS, Williams JB, Boyle MB, Folander K, Luneau CJ, Antanavage J, Oliva C, Buhrow SA, Bennett C, Stein RB, Kaczmarek LK (1990) Cloning and expression of cDNA and genomic clones encoding three delayed rectifier potassium channels in rat brain. Neuron 4:929-939.

Takimoto K, Fomina AF, Gealy R, Trimmer JS, Levitan ES (1993) Dexamethasone rapidly induces $\mathrm{Kv} 1.5 \mathrm{~K}^{+}$channel gene transcription and expression in clonal pituitary cells. Neuron 11:359-369.

Tempel RI, Papazian DM, Schwarz. TI, Jan YN, Jan LY (1987) Sequence of a probable potassium channel component encoded at Shaker locus of Drosophila. Science 237:770-775.

Thomas PK, Berthold C-H, Ochoa J (1993) Microscopic anatomy of the peripheral nervous system. In: Peripheral neuropathy, 3d ed (Dyck PJ, Thomas PK, eds), pp 28-73. Philadelphia: Saunders.

Trimmer JS (1991) Immunological identification and characterization of a delayed rectifier $\mathrm{K}^{+}$channel polypeptide in rat brain. Proc Natl Acad Sci USA 88:10764-10768.

Verkhratsky A, Hoppe D, Kettenmann H (1991) Single $K^{+}$channel properties in cultured mouse Schwann cells: conductance and kinetics. J Neurosci Res 28:200-209.

Wang H, Kunkel DD, Martin TM, Schwartzkroin PA, Tempel BL (1993) Heteromultimeric $\mathrm{K}^{+}$channels in terminal and juxtaparanodal regions of neurons. Nature 365:75-79.

Wang H, Kunkel DD, Schwartzkroin PA, Tempel BL (1994) Localization of Kv1.1 and Kv1.2, two channel proteins, to synaptic terminals, somata, and dendrites in the mouse brain. J Neurosci 14:4588-4599.

Wiley CA, Ellisman MH (1980) Rows of dimeric-particles within the axolemma and juxtaposed particles within glia incorporated into a new model for the paranodal glial-axonal junction at the node of Ranvier. J Cell Biol 84:261-280.

Wilson GF, Chiu SY (1990a) Regulation of potassium channels in Schwann cells during early development of myelinogenesis. J Neurosci 10:1615-1625.

Wilson GF, Chiu SY (1990b) Ion channels in axon and Schwann cell membrane at paranodes of mammalian myelinated fibers studied with patch-clamp. J Neurosci 10:3263-3274. 